I would like to make it quite clear that this is not an attack on my medical colleagues alone. I am aware that many of my pharmacist colleagues are in the same bewildered otate as the more unobservant doctor. This Is deplorable. I would say that pharmacists who do not know their drugs really ought to ask themselves whether they can, in all conscience, still-call themselves "pharmaceutical chemists." I would appeal to all, doctor and pharmacist alike, to take drugs more seriously. If we do not know our tools how can we pick the best for the task in hand and gauge the vigour with which to use them? There are, these days, aids galoreour patients are entitled to expect us to use them.-I am, etc.,

$$
\text { A. P. Launchbury, }
$$
South Birming Chief Pharmacist. Selly Oak Hospital, Committee.

Birmingham.

\section{Diagnosis of Suspected or Occult Pulmonary Embolus}

SIR,-Previous histopathologieal studies have indicated that massive pulmonary embolism may be followed by an episode of fatal disseminated intravascular coagulation. ${ }^{1}$ An important question arising from this work is whether low-grade disseminated intravascular coagulation is a common but unrecognized sequela of non-fatal pulmonary embolism. Confirmation of this could be of some importance, as recent technical developments in the diagnosis of occult intravascular coagulation and fibrinolysis, using the tanned red cell haemagglutination immunoassay for the quantitation of serum fibrin/fibrinogen degradation products (F.D.P.), might be used as either supportive evidence of a clirical diagnosis or to detect occult pulmonary embolism. During a pilot study of the changes of serum F.D.P. in response to surgery and acute myocardial infarction evidence was obtained which indicates that such a hypothesis is worthy of further investigation.

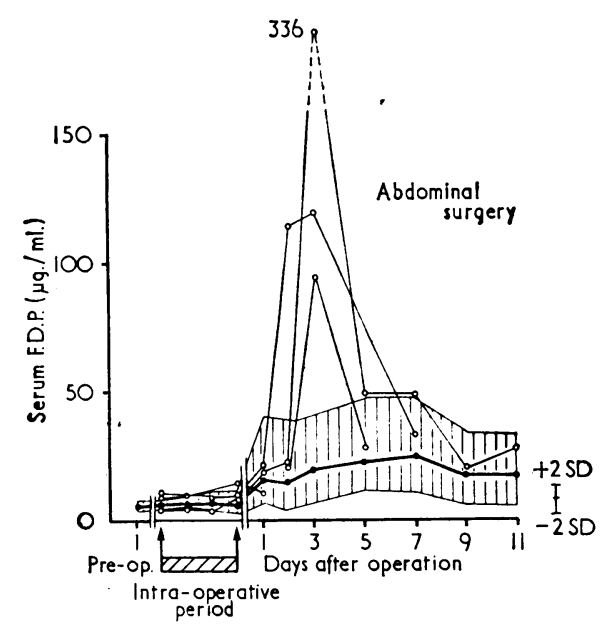

FIG. 1.-The changes of serum F.D.P. in response to abdominal surgery in 11 female patients. The closed circles represent the mean values of eight of the patients and the shaded arca the range. The open circles are the values arca the range. The open circles are the values obtained from the remaining three patients (see
text). The mean +2 S.D. values were obta:ned from 50 healthy age and sex matched resting from 50 healthy age and sex
The opcrative group of patients consisted of 11 premenopausal women who, apart from their primary gynaecological complaints, were considered to be healthy. Five underwent tota hysterectomy, three partial hysterectomy, and three unilateral salpingo-ophorectomy. Twelvc patients were also studied with the clinical diag nosis of acute myocardial infarction, which was subsequently confirmed by electrocardiographic and serum enzyme abnormalities. The firs venous blood sample was obtained within six hours of the onset of chest pain. All received oral anticoagulants on admission; none received digoxin or diuretics during the study. The serum F.D.P. immunoassay was performed as described previously. ${ }^{23}$ The person responsible for the assays had no prior knowledge of the source of the serum samples.

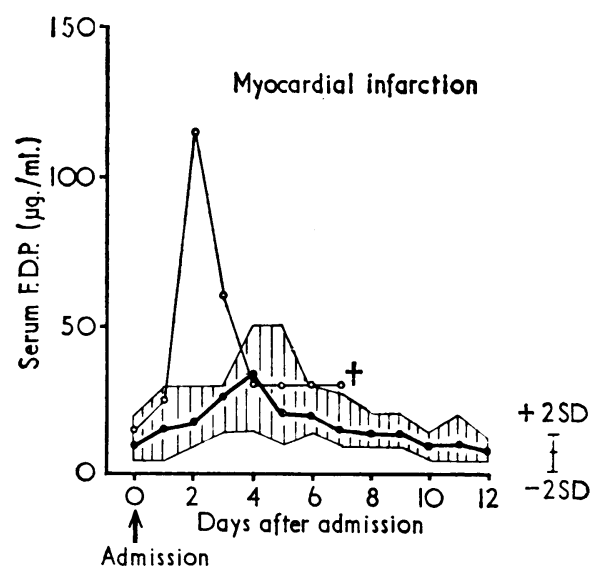

FIG. 2.-The changes in serum F.D.P. in response to acute myocardial infarction in 12 patients. The closed circles represent the mean valucs of 11 of the patients and the shaded area the range. The open circles are the values obtained from the remaining patient (see text) The mean \pm 2 S.D. values were obtained from 50 healthy age and sex matched resting controls.

The results from both groups of patients are summarized in Figs. 1 and 2. There was an increase in the mean serum F.D.P. following both abdominal surgery and acute myocardial infarction which was highly significant $(P<0.001)$ on days 5 and 7 in the postoperative group and days 3 and 4 in the myocardial infarction group. In three of the 11 surgical patients there was a sudden increase on the third postoperative day which was well outside the range found in the remaining eight patients. Reference to the clinical notes revealed that in one of these patients the diagnosis of pulmonary infarction was made on the same day that a serum F.D.P. value of $336 \mu \mathrm{g} . / \mathrm{ml}$. was recorded. There was no clinical evidence of pulmonary embolus, infarction, or venous thrombosis in the two other patients whose serum F.D.P. peaked during the study. One of the 12 acute myocardial infarction patients also produced a peak of serum F.D.P. without clinical evidence of pulmonary embolus or venous thrombosis. However, during the night on the ninth day after admission he died suddenly and unexpectedly. Necropsy revealed the cause of death to be multiple pulmonary emboli.

It would be premature to conclude from this small pilot study that the quantitative assay of these serum polypeptides will prove to be useful in establishing the diagnosis of suspected or occult pulmonary embolism There are many other clinical conditions in which disseminated intravascular coagulation and fibrinolysis occur. ${ }^{1}$ Moreover, venous thrombosis, without pulmonary embolism or infarction, may have been responsible for some of the serum F.D.P. peaks in the present investigation, a!though five cases of acute femoral venous thrombosis, without clinical evidence of pulmonary embolus, studied in non-surgical wards, have failed to show serum F.D.P. values above $30 \mu \mathrm{g} . / \mathrm{ml}$. It is also possible that a significant peak in serum F.D.P. is associated with pulmonary embolus only if it proceeds to infarction.

There is no doubt that a major practical problem in any possible future development of this work is the laborious nature of the type of immunoassay used and the duration required (12-24 hours) before a result is available. However, we have evidence to show that the capillary technique of Israels et al. ${ }^{5}$ can solve the latter problem, and further developments, currently under investigation in this laboratory, may provide an immunoassay which is rapid and simple to execute and perhaps suitable for complete automation.-We are, etc.,

$$
\begin{aligned}
& \text { J. D. Cash. } \\
& \text { D. G. Woodfield. } \\
& \text { P. C. Das. } \\
& \text { A. G. E. AllaN. }
\end{aligned}
$$

South-east Scotland Regional

\section{Blood Transfusion Centre, Royal Infirmary, Edinburgh. \\ REFERENCES}

1 McKay, D. G., Franciosi, R., and Zeller, J., American fournal of Cardiology, 1967, 20, 374 , and Cash, J. D., British Medical fournal, 1967. 4, 718 .

4, 718.
and Cash, D. D., Cole, S. K. Alitish Medical fournal, 1968, and 665 .

McKay, D. C., Disseminated Intravascular Coagulation, 1965. New York, Harper and Row.

Israels, E. D., Rayner, H., Israels, L. G., and Zipursky, A., fournal of Laboral
cal Medicine, 1968, 71, 333 .

\section{Cyclophosphamide and the Nephrotic Syndrome}

SIR,-I was interested in your leading article (15 March, p. 660) concerning the use of cyclophosphamide for the treatment of children with the nephrotic syndrome. I noted your cmission of reference to our work on this subject, ${ }^{1}$ which reached essentially the same conclusions as outlined in your leading article and in the excellent article by Drs. M. W. Moncrieff, R. H. R. White, C. S. Ogg, and J. S. Cameron in the same issue (p. 666).

We believe that the beneficial effect obtained by this drug casts further doubt on the so-called "immunosuppressive" mechanism of action of this agent in this condition, and in fact attests to our ignorance of the mechanism of action of any of these newer drugs in the various forms of glomerular disease. Our subsequent experience with this agent in children with the nephrotic syndrome is similar to that which we originally reported, and it is our opinion that a clear definition of the specific indications for its use is beginning to emerge. We have been concerned by the occasional instances of fatal varicella in children receiving cyclophosphamide for the nephrotic syndrome which have been reported by others, and for this reason we urge the greatest caution in the use of this drug in patients who have not experienced varicella unless it is possible to avoid exposure to this 
infectious disease during the course of treatment.

It is our opinion that controlled studies will be necessary to establish the specific indications for the use of this and other immunosuppressive agents in the treatment of renal disease. In so far as is possible a precise definition of the clinical, laboratory, and light, electron, and immunofluorescence microscopic features of the patients treated with such agents should be obtained in order that investigators from different centres may be aware of the precise entity being treated. -I am, etc.,

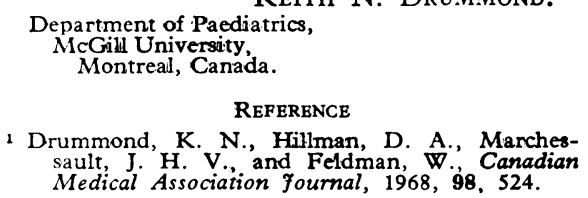

Keith N. DRummond.

\section{Junior Staff and the B.M.A.}

SIR,-The leading article on junior staff (17 May, p. 399) was as good an exposition of the party line as one could wish for. To those of us involved in hospital junior staff affairs the arguments and conclusions were all too familiar. The principal difficulty that we have had to face is the inability of the older members of the profession to see the other side of the case, and to realize that junior staff are in earnest and consider that they have a reasonable case.

The covert paternalism which has frustrated any progress in this conflict is a danger not only to the B.M.A. but to the profession. Any association which valued its future would have come to terms with its younger members had it wished to survive. One important point that was not brought out in the leader is the fact that all hospital junior staff, the J.H.D.A., and the H.J.S Group Council are almost unanimously behind the constructive proposals embodied in the J.H.D.A. Memorandum and the H.J.S. Group Counoil resolutions of March 1968 (Supplement, 2 March 1968, p. 56).

One of the most depressing features of the debates on the subject in the C.C.H.M.S and the Council has been the almost total ignorance of the nature of these proposals. It has been said that the hospital junior staft wish to go it alone, leading to a proliferation of committees resulting in less efficiency and greater cost. Both these assumptions are false. The junior staff have proposed that the H.J.S. Group Council should be changed into a committee of equal status to the senior staff committee and propose:

1. That these committees should be elected on a geographical basis to determine the broad lines of policy for all hospital staff.

2. That there should be a joint executive committee numbering approximately twelve, and consisting of roughly equal numbers of senior and junior staff. This committee would be responsible for the elaboration of detailed policy along the lines laid down by the main committees and where necessary preparing the case for negotiation with the Department of Health and Social Security and other bodies.

3 . The joint executive would appoint a small number of negotiators, possibly two or three for each negotiation. The negotiators would be chosen for their ability and knowledge of the subject.

4. To safeguard the main committees and to prevent the mistrust that bedevilled negotiations

\section{"Kwok's Quease" in Britain}

SIR,-According to the leading article on "Kwok's Quease" (24 August 1968, p. 447) no reports from Britain had appeared. I now report that while in hospital for "traction" for a slipped disc (L 3-4) I was made so ill by the very tasty soup there that I thought I was having septicaemic rigors and discharged myself to die at home. Inquiry at the hospital has established the fact that the soup contained glutamate.

Other fellow sufferers from "discs" and other coeliac and colonic and enteropathic and skin effects have since then recounted their own attacks of "agues" from glutamate. It must be common but brushed of as "neurotic" by many doctors.-I am, etc., Bishop's Stortford,
Herts.

$$
\text { Robert A. R. Wallace. }
$$

over the last 20 years all agreements would have to be ratified by the main committees before they could become operative.

The introduction of such a system would speed up the work of the committees and would diminish the number of people involved in committee work without prejudicing the representative function of the main committees. Such a system would certainly be more efficient and possibly less expensive, and it would not give hospital junior staff the ability to go it alone.

The leading article stated that the representation issue was tending to overshadow more important matters and that this was not the time to pursue it. Six months ago we would have agreed. However, this is a time when major changes in the profession are inevitable and are occurring rapidlyimportant changes in training, career structure, and administration. Indeed, there has not been such a critical period in the history of the profession since 1946-8.

It has become increasingly clear to us, who have negotiated on behalf of hospital junior staff on these matters, that we are being excluded progressively from the making of really vital decisions. The constitution of the group which met the G.M.C. with regard to specialist registration and the group which met the Minister in regard to the Green Paper are examples of this. It is our belief that hospital junior staff must be effectively represented at all points in this decisionmaking process. We have supported our colleagues in bringing the representational issue forward at this time, as it has never been more important.

The decision of the J.H.D.A. to go it alone was not taken lightly, and the fact that it was considered necessary was of grave concern and deep regret to both of us. If our senior colleagues in the B.M.A. are prepared to make the necessary changes there is no reason why a functional unity within the profession cannot be achieved quickly and at little cost.

We have shown ourselves willing to work hard, to elaborate constructive proposals, and to negotiate. Unhappily we have not made progress. It is our hope that our senior colleagues in the B.M.A. will reconsider the matter and put forward constructive proposals in the near future, and that a just and lasting peace can be achieved before irreparable damage is done to the profession.-We are, etc.,

Francis Pigott, Chairman, H.J.S. Group Council. Chairman, J.H.D.A.

KATHARINE F. BRADLEY, Vice-chairman, H.J.S. Group Council.
Vice-chairman, J.H.D.A.

London W.C.1.

\section{University Teachers' Pay}

SIR,-Before the recent pay awards many professors with clinical contracts had salaries exactly similar to some of their senior lecturer colleagues. The effect of the pay awards will have been to give them less than these same senior lecturers, since senior lecturers' salaries were assimilated to the consultant scales before application of an $8 \%$ increase, while professors' salaries received an $8 \%$ increase without prior assimilation.

Since one would not wish to believe that the University Grants Committee failed to realize this, one can only assume that it was intended. Nevertheless, it would be interesting to know the reasons which have prompted this change.-I am, etc.,

$$
\begin{gathered}
\text { Department of Social and } \\
\text { Preventive Medicine, } \\
\text { University of Manchester. }
\end{gathered}
$$

Alwyn SMith.

University of Manchester.

\section{Difficulties of Regional Consultants}

SIR,-There are now wide variations present in relation to consultant appointments.

Trainees, depending on the specialty, can achieve their consultancy after between two and eight years of training. Some regional consultants have virtually no junior staff or need to rely wholly upon the services of overseas graduates. On the other side of the coin, ample junior staff willing and having time to carry out research as well as the routine work abound in the undergraduate and postgraduate institutions. Variation in staff must affect the merit award distributions.

Some areas are provided with many private beds and nursing-homes. On the other hand, the invidious pruning of private accommodation in the regional hospitals has reduced private practice in some areas to an absurdity. Again, in the smaller hospitals some consultants are on call or working for the entire week day and night.

It is now clearly seen that the unattractive and overworked posts in the periphery must be modified by increasing the consultants' stipend. It is only by some such means that the "crumbling edifice" of regional hospital consultants can be halted.-I am, etc.,

$$
\begin{aligned}
& \text { Letchworth. JOHN SHIPMAN. } \\
& \text { Herts. }
\end{aligned}
$$

\section{Budgeting in the N.H.S.}

SIR,-I was very interested to read "Personal View" by Andrew House (10 May, p. 378). I recently had the privilege of attending one of the finest courses I have 